\title{
The Realization of the Right to Education in Slovenia
}

\author{
Marjan Šimenc, Faculty of Education, University of Ljubljana \\ and Educational Research Institute, Slovenia \\ Zdenko Kodelja, Educational Research Institute Slovenia
}

T

he right to education is a right which has a strong normative foundation in international law. It was first directly defined in Article a number of other international documents, including the International Covenant of Economic, Social and Cultural Rights and The United Nations Convention on the Rights of the Child. At the European level, another very important document regarding this topic is the Convention for the Protection of Human Rights and Fundamental Freedoms. The right to education is otherwise included among cultural rights (Nowak, 1995, p. 189), although it is closely interrelated with other human rights.

According to experts, the goals of the right to education are worked out in greatest detail in Articles 28 and 29 of the Convention on the Rights of the Child. This Convention is the most universally valid and acknowledged document on human rights, as it was as of today ratified by all except two UN member states.

The attention towards the right to education is by no means accidental, as the right to education is important for both children, to whom it refers directly, and for modern society which is supposed to be a society of knowledge, and hence the education is of key importance for it. However, the right to education holds a special meaning also due to its specific position among human rights: it is a precondition for number of other human rights (Nowak, 1995, p. 189). On the one hand, it helps to guarantee the possibilities to form autonomous individuals and for obtaining

I This article is a revised, upgraded and translated version of the previously published article (Šimenc and Kodelja, 20I5). 
education, which is today a necessity - although far from being adequate - condition for a decent life; and is on the other hand closely interrelated with an economically successful society and deliberative democracy, with both of them presuming educated and enlightened citizens for their existence. ${ }^{2}$ We could even argue that numerous civil and political, but also economic, social and cultural rights can be successfully implemented only in an environment which has achieved a certain level of education.

The right to education is formally defined in such a way that it does not include only the growth of a person and his/her dignity, but also development of respect for human rights. Point I (b) of Article 29 of the Convention on the Rights of the Child thus clearly states: 'States Parties agree that the education of the child shall be directed to the development of respect for human rights and fundamental freedoms, and for the principles enshrined in the Charter of the United Nations.'

The field of education is a place where the dissemination of information regarding rights and moulding individuals in such a way that they shall respect and fulfil human rights is entered in the sphere of rights. It is a place where rights at a rights level attempt to ensure conditions for their realisation. Formal level, i.e. designing documents stating rights, and a signature of individual states, which binds it at the formal level to respect the rights listed in the signed document, is namely not enough for asserting rights. This formal level is necessary, but not sufficient; hence citizens need to demand from authorities to really respect the rights through their actions. On the other hand, citizens also need to be prepared to respect and carry out legislation and other legal measures for implementing international obligations. This can be asked and realised only by citizens who know human rights, and above all understand their meaning and feel themselves obliged to respect them. Education is one of such tool, where the mechanisms for establishing the conditions for executing these rights can be entered in the formal structures of rights. Education is a place where the voice for demanding and defending rights is formed, and where the rules of discourse which supports it are formed. We need to emphasise a specific status of this entry: the right to education is a right which can help realising human rights when implemented; but can perform this function only if it is carried out itself. So, it already assumes for its implementation that human rights are put into effect. Or it assumes that at least one of the human rights is already fulfilled, namely the right to education.

2 For Buchanan, it is exactly benefits gained from (basic) education by both individuals and society that justify the inclusion of the right to education on the list of human rights, guaranteed by international law instruments (Buchananm, 2013, pp. 160-162). 


\section{The Right to Education Is Not Only the Right of the Child}

It seems that the right to education refers mainly to children. However, the right to education is not a right acknowledged only to children. The right to education is a universal human right. As already mentioned, it is as such written in the Universal Declaration of Human Rights and in some other documents on human rights. ${ }^{3}$ Therefore the explanation that the Convention on the Rights of the Child gives rights to children as children (Archard, 2004, pp. 60) is wrong; or in other words, that it grants them rights because they as children differ from adults and are not recognised to have all rights given by other international documents on human rights to every person. Children have this right recognised already before the implementation of the Convention on the Rights of the Child, as this right was acknowledged to every single human being, including children. On the other hand, everyone has this right even when he/she is not a child anymore. Therefore he/she can exercise it as an adult as well. Even more so, in countries such as Slovenia, where young people usually start their studies when they are already 18 years of age, the great majority of them even cannot exercise part of this right, namely the right to higher education accessible to all. ${ }^{4}$ Apart from that the right to primary education, which is in Slovenia and in line with the Convention is compulsory,'s is not really a right, but an obligation. If the essence of the right or of that what makes a right a right in the true sense - and not an obligation or a duty - lies in the freedom of the subject of the right to implement or not the right acknowledged to him or her, then the right to education at primary school level, which is compulsory by law, cannot be a right, since a child (or his/ her parents) cannot freely decide that he/she or they won't implement the right to education (in the case of compulsory primary school). Hence, we

3 Article 26 of the Universal Declaration of Human Rights states: I) Everyone has the right to education. Education shall be free, at least in the elementary and fundamental stages. Elementary education shall be compulsory. Technical and professional education shall be made generally available and higher education shall be equally accessible to all on the basis of merit. (2) Education shall be directed to the full development of the human personality and to the strengthening of respect for human rights and fundamental freedoms. It shall promote understanding, tolerance and friendship among all nations, racial or religious groups, and shall further the activities of the United Nations for the maintenance of peace. (3) Parents have a prior right to choose the kind of education that shall be given to their children.' We can find similar formulations in the International Covenant on Economic, Social and Cultural Rights (Article 13), and in the Convention against Discrimination in Education (Articles 4 and 5 ).

$4 \quad$ States Parties ... Make higher education accessible to all on the basis of capacity by every appropriate means (Convention on the Rights of the Child, Article 28c).

5 State Parties ... Make primary education compulsory and available free to all (Convention on the Rights of the Child, Article 28a). 
might argue that the right to education for children and parents is really a duty at the primary school level. This special status of right-obligation is related to the fact that this is the essential right, which then allows other rights to be implemented as rights. The same as human rights are an obligation for a government in order to allow its citizens to enjoy them as rights, the right to education is an obligation for children and parents in order to enable them to enjoy all other rights as rights.

\section{The Fulfilment of the Right to Education: A Review}

If we take a look at the preamble to Article 28 of the Convention ('States Parties recognize the right of the child to education, and with a view to achieving this right progressively and on the basis of equal opportunity, they shall, in particular ...'), we can say that the Republic of Slovenia strives to 'achieve this right progressively and on the basis of equal opportunities'. The state tries to provide equal opportunities for education - without which there cannot be a just educational system - with various measures and mainly in two ways: firstly, by providing equal access to education on the basis of an individual's merits, his or her capacities and invested effort (by providing an equal scope of free education to everyone; by enabling the differentiation of lessons; by the inclusion of children with special needs when this is more beneficial for them than education in special schools, etc.); and secondly, by providing an equal basis at the start of education. An important measure for providing equal opportunities in the sense of an equal basis, is an improvement of the initial situation of children from culturally or socially deprived environments by including as many children as possible in good quality pre-school programmes. Around three quarters of all pre-school children now already attend kindergarten, which reduces the initial differences in their 'readiness for school'.

Slovenia also fulfils the obligation taken on by signing the Convention to provide compulsory and available free to all children - 'primary education compulsory and available free to all' (28.I.a). It is worth emphasising that free education is in this context meant as the opposite to payable education, namely as a possibility of education without paying a fee. But the absence of fees does not necessarily mean that education is completely free. The costs of school supplies are so high that many parents cannot cover them by themselves. Therefore, they are forced to ask various charities for help. State measures, such as the establishment of a textbooks fund, and free textbooks in the first three years of primary

6 According to the Statistical Office of the Republic of Slovenia for 2012. 
education, are obviously not enough. Apart from that, schools increasingly more often offer extra-curriculum, premium activities, which may have an extra levy, such as additional open-air school, school trips and excursions and various courses.

We can come to similar conclusions for further lines of the first paragraph of Article 28: Slovenia provides 'higher education accessible to all on the basis of capacity by every appropriate means' (28.I.c); 'educational and vocational information and guidance available and accessible to all children (28.I.d); and takes 'measures to encourage regular attendance at schools and the reduction of drop-out rates (28.I.e). It furthermore takes 'all appropriate measures to ensure that school discipline is administered in a manner consistent with the child's human dignity' (Article 28, Paragraph 2). 'We can also argue that Slovenia 'promotes and encourages international cooperation in matters relating to education, in particular with a view to contributing to the elimination of ignorance and illiteracy throughout the world' (Article 28, Paragraph 3), although this aspect is not to the fore of public attention nor to the forefront of Slovenia's efforts in times of deglobalisation.

It goes a similar vein for Article 29., where Slovenian's educational system is directed to: 'the development of the child's personality, talents and mental and physical abilities to their fullest potential' (29.I.a); 'the development of respect for human rights and fundamental freedoms' (29.r.b); 'the development of respect for the child's parents, his or her own cultural identity, language and values, for the national values of the country in which the child is living' (29.I.c); 'the preparation of the child for responsible life in a free society, in the spirit of understanding, peace, tolerance, equality of sexes, and friendship among all peoples, ethnic, national and religious groups and persons of indigenous origin (29.r.d); and to 'the development of respect for the natural environment' (29.I.e). Slovenia also respects the principle that 'no part of the present article or Article 28 shall

7 The second paragraph of Article 28 advocates a special caution pertaining the implementation of discipline, which could be in contradiction to human dignity. Discipline in school therefore gets special attention. Legal procedures have assured that school discipline is not implemented in an inappropriate way. However, it is less evident from the article that an excessive caution pertaining the implementation of discipline can also be in contradiction with the child's dignity. If discipline itself loses its reputation; if it seems that its implementation is awkward, reservations regarding disciplinary measures, arising from excessive caution, can also create conditions which aren't in line with the child's dignity. This perspective is less obvious from the formulation of the article: the article itself directly discusses discipline alone, but it should be in the context of the entire convention logically understood in a broader sense of the right to learning environment which shall be in line with the child's dignity. The right to such learning environment can be infringed by the lack of discipline. 
be construed, so as to interfere with the liberty of individuals and bodies to establish and direct educational institutions' (29.2).

A detailed review of fulfilling the obligations arising from these two and other articles, if they have consequences for education, would be too extensive for the limited length of this paper. A quick review of the articles could create an impression that Slovenia respects the rights of the child to a great extent; however the review of reports on fulfilling the Convention shows that this is a process where the answer to the question as to whether the Convention is being put into effect is not a simple 'yes' or 'no' in certain fields. It is also not about a comparison with other countries, but more about a process of following trends in certain fields gradually, and about the improvement of conditions, which takes a lot of time, effort and means. Hence this paper is focused on just those few moments where the Convention calls for more intervention.

The first moment shall be related to a question which is in a way very paradigmatic, and linked to the rights of the child, namely to the question of protecting the rights of minorities. The second one shall be related to a question which is sometimes not even perceived as a question from the rights of the child's perspective; or can its exposure be dealt with as somehow problematic, as it can lead to the violation or at least limiting the notion of the rights of the child, namely the question of the quality of knowledge. The third issue is the issue where the biggest legislative changes have occurred since the adoption of the Convention by Slovenia; but it is at the same time also a topic where the rights of the child and human rights are often invoked, although the referencing can be somehow misleading from time to time.

\section{The Education of Roma Children (and Other Minority Groups)}

Our starting point will be upon the emphasis of the 'respect for the child's parents, his or her own cultural identity, language and values, for the national values of the country in which the child is living, the country from which he or she may originate, and for civilizations different from his or her own' (29.I.c). We have chosen this emphasis since Slovenian rapports regarding the implementation of the Convention on the Rights of the Child, assigned in Article 48, most often focus on the issue of the education of Roma children. The Combined Third and Fourth Report of the Republic of Slovenia on the implementation of the Convention from 2010 thus states, numerous measures regarding the improvement of Roma children's right to education, including the ban to form classes with Roma pupils only; standardisation of Roma language as a basis for teaching Roma 
language; an introduction of Roma assistants; and an introduction of Roma Culture as an optional subject.

Despite numerous measures introduced by Slovenia to improve the education of Roma children, the UN Committee on the Rights of the Child in its 2013 Conclusions of the Committee on Slovenian Report regarding Roma children's rights to education points towards the poor academic success of Roma children at primary school level, and a large proportion of early school leavers at all levels of education. It also stresses that schools 'still use outdated materials which intensify stereotypes, prejudice and negative perception of Roma'. It recommends 'a removal of all references to the Roma population, which are connected with prejudices from school textbooks, and implementation of measures for encouraging a culture of tolerance and multiculturalism in schools (Committee on the Rights of the Child, 2013).

National reports for the period after 2010 aren't available, but there is the Interim Alternative Report on the Implementation of the Convention on the Rights of the Child (Zipom, 2016, p. 31), which was prepared by a network of NGOs from the Zipom Centre; and Annual Reports of the Ombudsman of the Republic of Slovenia (Ombudsman, 2020, p. 79), which draw attention that the Roma right to education remains ignored and needs to be improved.

An alternative report points towards the insufficiencies and violations of the right to education for refugee children and children from ethnic minorities. On a general level, this topic is addressed to in annual general reports by the Special Rapporteur on the Right to Education, which draws attention to deficiencies at a global level. From these reports, we can infer elements which could be problematic in Slovenian's educational system; or about which we needed to report on potential progress if official reports on the situation in Slovenia existed. The 2017 report thus relates to the question of inclusion (Boly Barry, 2017). Within this context, it also exposes the rights of persons with disabilities to inclusion into the general educational system. Slovenia could report on (the absence of) progress regarding inclusion in relation to the Placement of Children with Special Needs Act (Act, 2017). Especially because the 20II White Paper on Education in the Republic of Slovenia (Krek, Metljak) proposes certain solutions (reference schools, support centres) which would make the inclusion of children with special needs easier, but the proposals have not been realised. The rapporteur in his report draws attention to classes in their mother tongue for pupils from linguistic minority groups. Slovenia could mention additional Slovenian language classes for immigrant children who do not speak Slovenian, and which were introduced 
into Slovenian legislation for primary and secondary school education, and of afternoon supplementary classes of mother tongues for immigrant children. Regarding the adequacy of these measures, we could draw from the analyses by SIRIUS, the European Network on Migrant Education, which is active in Slovenia as well.

Let us add that the latest report by the special rapporteur relates to the realisation of the right to education during the Covid crisis (Boly Barry, 2020). The report does not refer especially to Slovenia, although general reports about the endangerment of the right to education apply to Slovenia, too. The report draws attention to groups of children whose right to education was most affected by the Covid crisis and consequential schooling from home, and proposes a surprising attitude towards the digitalisation of education:
All States should, as a matter of urgency, adopt special, targeted meas- ures, including through international cooperation, to address and miti- gate the impact of the pandemic on vulnerable groups, as well as commu- nities and groups subject to structural discrimination and disadvantage. In many contexts, this will mean prioritising the most accessible, low-or- no-tech' approaches in distance learning ... (Boly Barry, 2020, p. 19)

Besides, the report includes the position regarding the nature of education, and an implicit recommendation regarding the development of digitalisation of education, in order to prevent possible violations of the right to education. The recommendation is relevant to Slovenia as well: 'The digitalization of education should never replace onsite schooling with teachers. Should distance education become the new paradigm for education after the end of the pandemic, it would affect the heart and purpose of the right to education. Onsite and face-to-face education enables teachers not only to provide content, but to ensure it is understood and well received. Besides, education goes much beyond a single objective of transmitting didactic knowledge, and aims at developing socio-emotional skills, critical spirit and creativity, citizenship and mutual understanding between groups that need to interact and mix in order to live in and build a peaceful society, and at connecting children to nature and to their environment. Education is a social act of a community of learners that require real human interactions.' (Boly Barry, 2020, p. I2)

This report differs from others in that it does not report only upon violations of the right to education which have already happened, but also in tendencies and future violations. This is in a way in line with the report of the 2019 special rapporteur report, talking about 'a particularly forceful preventive potential of the right to education in the very early stages, 
before warning signs are apparent. That role is to be linked with the aims of education and the right to inclusive and equitable quality education' (Boly Barry, 2019, p. 2). The same as the right to education has the power of prevention, the report on carrying out this right in the time of corona crisis also attempts to act preventively, so that the response to the crisis would not lead to narrowing the right to education.

\section{Question of the Quality of Knowledge}

The formulation of educational goals from the Convention regarding the rights of the child to develop his/her capacities, perspectives, knowledge, skills and achievements shows a different logic, so we need to ask ourselves about the relation of these two perspectives. It is patently clear that children have not developed their capacities, if they do not possess the basic knowledge enabling them the successful inclusion and life in society. However, this argument has not yet developed the connection between knowledge and the development of a child's capacities. Furthermore, the Convention on the Rights of the Child is based on a perspective which doesn't put knowledge, skills and achievements at the centre of attention, which can raise the feeling that they are of less importance from the rights of the child perspective. This would call for the articulation of a broader view which would show that the child has always lived in the world and society, so even his/her capacities need to be considered within this framework. However, we don't need to develop this framework here, there is namely another path which shows the importance of knowledge to the child's right to education: from definitions, it seems more like the right of the child to develop his/hers capabilities. From the Convention's perspective, the concept of equal opportunity of children is brought to the fore. And this is exactly where a school system when it does not look after the quality of education or knowledge of the children turns out to be unjust to some children and in contradiction with the principles of equal opportunities.

Let us develop this further. The attention to the implementation of the Convention is often focused mainly on the negligence of emotional and social development and the influence of knowledge measurement on marginal groups. ${ }^{8}$ The element which relates directly to knowledge and

8 When focusing on quality, they can describe it very narrow. In the context of discussion about the right of the child, a broader context of education, learning environment, the number of well educated teachers, access to learning tools, etc. is emphasised, and the attention is drawn to the fact that academic success cannot be the sole measure to achieve good quality upbringing and education, and can lead to the narrowing of upbringing and education to the number of points gained at tests, and the placement of a country on an internationally comparable charts. 
the empowerment of pupils which goes with it, is less emphasised: 'As an empowerment right, education is the primary vehicle by which economically and socially marginalized adults and children can lift themselves out of poverty and obtain the means to participate fully in their communities."

Statistically speaking, general academic success in Slovenian primary schools used to be, on-the-whole normally distributed. This means that the-majority-of pupils were $\mathrm{C}$-students, while there were less $\mathrm{D}$ - and $\mathrm{B}$-students and a few F- and A-students. Those times are gone. Less than a decade ago, more than one third of pupils finished primary school as A-students. How could have such a big difference occurred? There are at least three possible explanations. First, children have much better knowledge today, secondly, the learning content is less demanding, and thirdly, the marking criteria has changed. The first explanation would be convincing if we could prove that the complexity of learning content or strictness of marking have not changed significantly; the second would be convincing if it was true that neither the knowledge children possess nor the strictness of marking have not changed significantly; and the third, if the knowledge children possess and the complexity of learning content have stayed largely the same. Such thinking might seem simplified, as it is not necessarily true that only one of the three explanations is correct. All three can be correct. Even so, this does not eliminate the underlying problem, i.e. how to explain the cause of this change. The only difference is that in this case, we would need to show how much each of these explanations contributes towards the explanation of this change. Therefore, we can say that the increase in the number of A-students would be good if the first explanation was correct; and bad if the second or the third explanation was true. The increased number of A-students is not bad. It is bad only, if it is a result of the decreased complexity of the learning content or lower criteria for marking. In the past, school authorities obviously perceived the first explanation to be wrong, as their arguments for eliminating overall achievement which came into force with the change of Basic School Act in the school year 2008/09 included a great increase in the A-student numbers. Since they omitted to mention a decrease in learning content complexity as a possible cause and stressed upon the pressure parents exerted on teachers to round the marks upwards at the end of the school year, we could surmise that they saw the cause for the increase in the A-student numbers in a lacking in the strictness of marking. However, even if a

9 Committee on Economic, Social and Cultural Rights. General Comment I3, The right to education. 
lacking in the strictness in marking was the actual cause for the increase in the A-student numbers, the elimination of the overall achievement prevents us in establishing whether the strictness of marking has increased due to that. The only thing we know is that the before mentioned anomaly, which was expressed as an abnormal increase in the A-student numbers is not visible today because of this elimination. Nevertheless, the question remains whether this measure uprooted the cause for the then increase in A-student numbers. It is quite possible that this abnormality now continues with the marks for individual curriculum subjects. Certain data confirm this hypothesis. According to the National Examinations Centre, the rate of A-students in school years 2008-2010, if calculated only from the average of final marks for compulsory subjects for ninth class, was approximately five percent lower than before, while the rate of B-students increased by roughly the same percentage. However, more than $25 \%$ of pupils were still A-students. If we add B-students, we see that more than $60 \%$ of pupils were B- or A-students, while the rate of F- and D-students remained almost the same as the years previous, namely around eight percent. This distribution of academic success is abnormal.

We can conclude that the elimination of the overall achievement was not an effective measure, if assessed by its influence on the fairness of marking, which can be in this case defined as proportionality between the exhibited knowledge and received mark. The measure might have been efficient, but this doesn't mean that it was correct or necessary. If the parents put pressure on the teachers to give better marks, since the overall achievement decided whether their children could have enrolled at their general upper secondary school of choice or not, the school authorities should have stepped in and protected the teachers against these undue pressures and ensure the conditions which would have enabled the teachers to mark the pupils fairly. They could also ease these pressures by taking marks gained by the external assessment of knowledge into account for enrolment. However, they did exactly the opposite. They reduced the national assessment of knowledge to mere feedback for pupils and teachers, and which as such has practically no weigh in selective procedures for enrolment at secondary schools with limited admittance. ${ }^{10}$

\section{Private education}

The first attempts to regulate the formal situation of private education in Slovenia were presented in 1995 , in the White Paper on Education in the Republic in Slovenia which introduced starting points for education

IO For more on this, see Kodelja, 2012. 
reform in Slovenia. 'The Principles and Bases' defined the situation of private schools in principle with this formulation, 'The State needs to legally regulate and enable the establishment of private kindergartens and schools. This obligation arises from international documents, including the International Covenant on Economic, Social and Cultural Rights which provides parents the right to choose for their children schools, other than those established by the public authorities (if they conform to such minimum educational standards as may be laid down or approved by the State and are not in contradiction with established law).' (Krek, 1995, p. 16)

A more detailed definition of regulating private education in principle in the 1995 White Paper can be found within the chapter 'Design for governance arrangement of private schools and kindergartens'. The key definition seems to be the one related to the public and private sector relation, 'The public and private sector relation should be designed in such a way that private schools enrich public supply, allow greater choice for parents to contribute to greater adjustability of the system, and complement the public schools network (and not limit or undermine it). Mechanisms for monitoring the quality of private schools are necessary, at least where private schools fill in for public education.' (Krek, 1995, p. 238) Private schools are supposed to be designed so as to make public education more flexible and complement the public school network, where its capacities are insufficient, but should not lead to the closing down of public schools, because pupils enrolled at a private one.

Private schools (primary and general upper secondary) design their curricula by themselves, but the curricula need to be approved by a council of experts. The council of experts approve the curriculum when they establish that the curriculum provides 'equal education standard' (Organisation and Financing Education Act, Article 17). This demand is relaxed for the curricula performed by private schools according to special educational principles, and for which the council of experts need to establish that 'they provide minimal knowledge enabling the successful completion of education and were recognised by an appropriate union of these schools. With a proviso that these curricula are assessed during the entire schooling period for the first generation. This relaxation was adopted in order to enable the establishment of schools with a greater deviation of their curricula from the public school curriculum, that could not meet the demands for 'equal education standard' but have established themselves into the European educational environment with their education concept.

The existing arrangement designed in the first White Paper and has not changed in key elements in the 2or White Paper (Krek and Metljak, 
20II) therefore allows private initiative in education, but it is at the same time conditioned: the limitation refers to the quality of curricula. If a curriculum does not meet the required standards of quality, it is not publicly recognised, as it would not be in line with the children's right to education.

Slovenia thus provides the right to the establishment and management of private schools which is indirectly written in Paragraph 2 of Article 29 of the Convention ${ }^{\text {II }}$, and is also ensured by other international documents on human rights, ${ }^{12}$ although they refer more directly to the right of parents to educate their own children in conformity with their religious or philosophical convictions. The obligation of the state depends firstly on whether the right is understood as a positive or as a negative. A negative right means that each parent has the right to establish or choose the school for his/her children according to his/her own religious, moral convictions, while the state protects this right and doesn't limit it without adequate reasons and are provided by law. A positive right means that the state enables each parent to exercise this right by establishing and/or financing private schools. The dilemma pertaining to this is whether to regard this right as a negative or as a positive. Paragraph 2 of article 29 states that no part of the present article or article 28 'shall be construed so as to interfere with the liberty of individuals and bodies to establish and direct educational institutions'. The right in the Convention is thus written negatively - it is not allowed to prohibit private schools.

Nevertheless, a 1984 European Parliament resolution, which as a resolution is not legally binding for member states, tries to relate private education with a positive right, as it states amongst other things that: a) it cannot be the duty of the State to recommend or give preferential treatment either to denominational schools in general or to schools of a particular denomination; $b$ ) it is the duty of the State to provide the necessary

II No part of the present article or article 28 shall be construed so as to interfere with the liberty of individuals and bodies to establish and direct educational institutions, subject always to the observance of the principle set forth in paragraph $\mathrm{I}$ of the present article and to the requirements that the education given in such institutions shall conform to such minimum standards as may be laid down by the State.

I2 'The States Parties to the present Covenant undertake to have respect for the liberty of parents and, when applicable, legal guardians to choose for their children schools, other than those established by the public authorities, which conform to such minimum educational standards as may be laid down or approved by the State (International Covenant on Economic, Social and Cultural Rights, Article 13.3). We can find similar provision in the Convention against Discrimination in Education, "The States Parties to this Convention agree that: ... It is essential to respect the liberty of parents and, where applicable, of legal guardians, firstly to choose for their children institutions other than those maintained by the public authorities but conforming to such minimum educational standards as may be laid down or approved by the competent authorities.' (Article 5.b) 
facilities for State or private schools; and c) in accordance with the right to freedom of education, Member States shall be required to provide the financial means whereby this right can be exercised in practice and to make the necessary public grants to enable schools to carry out their tasks and fulfil their duties under the same conditions as in corresponding State establishments. $^{13}$

However, this Resolution is not legally binding, which is clearly seen from the arbitrations by the European Commission and the Court for Human Rights regarding the section of the Resolution regarding the obligation of the state to provide the financial means for private schools. This is an official explanation of article 2 of the Protocol to the Convention for the Protection of Human Rights and Fundamental Freedoms, which states, 'No person shall be denied the right to education. In the exercise of any functions which it assumes in relation to education and to teaching, the State shall respect the right of parents to ensure such education and teaching in conformity with their own religious and philosophical convictions.' (Digest, 1985, p. 743) In a few cases related to the quoted article, both the European Commission and the Court for Human Rights undoubtedly decided that the Protocol doesn't impose on the state the obligation to introduce and subsidise any kind of education at any level, nor that no parent or group of parents cannot put pressure on the state to establish new special schools or subsidise existing schools, if they educate in accordance with special cultural, religious or denominational tradition or particular academic specialisation. (Meredith, 1992, p. 26)

It follows that Slovenia realizes the demands of the Convention related to the possibility of establishing private schools. However, it is worth recalling that these demands are set negatively in the Convention, as an injunction on the prohibition for establishing private schools; and that the Convention as-a-whole conveys another idea, namely that children too, not only parents, should have a say on which school (public or private) they shall attend.

Last, but not least; the right of children in private schools in Slovenia has been determined by the Constitutional Court of the Republic of Slovenia more than once. The Constitutional Court has not changed the fundamentals of the established arrangement for private education, but it has decided that the state needs to finance private primary schools to the same extent as it finances public primary schools (for the compulsory part of the curriculum). It based its decision on the specific interpretation of the Slovenian Constitution and did not refer to the international

I3 »Parlamento Europeo: La libertà di scuola e di istruzione« (1984), in Pajer, I99I. 
documents regarding human rights, since it would not be able to do so (Šimenc and Tašner, 2016). This can be seen clearly in the report of the rapporteur of the human right to education which emphasised the importance of education as a general good (Sing, 2014).

\section{References}

Arcahrd, D. (2004) Children Rights and Childhood. London and New York: Routledge.

Bahovec, E., Kodelja, Z., Marjanovič, L., Zgaga, P., Kovač Šebart, M., Šimenc, M., and Krek, J. (1995) Načela in teoretična izhodišča. In Krek, J. (ed.). Bela knjiga o vzgoji in izobraževanju v Republiki Sloveniji, pp. II-34. Ljubljana: Ministrstvo za šolstvo in šport.

Boly Barry, K. B. (2017) Report of the Special Rapporteur on the right to education - Inclusion, equity and the right to education (No. A/72/496). New York: United Nations. Retrieved from: https://www.ohchr.org/ EN/Issues/Education/SREducation/Pages/AnnualReports.aspx (20 August 2020).

Boly Barry, K. B. (2019) Report of the Special Rapporteur on the right to education - Contributions of the right to education to the prevention of atrocity crimes and mass or grave violations of human rights (No. A/74/243). New York: United Nations. Retrieved from: https://www. ohchr.org/EN/Issues/Education/SREducation/Pages/AnnualReports. aspx (20 August 2020).

Boly Barry, K. (2020) Report of the Special Rapporteur on the right to education: Impact of the COVID-rg crisis on the right to education; concerns, challenges and opportunities (No. A/HRC/44/39). New York: United Nations. Retrieved from: https://www.ohchr.org/EN/Issues/ Education/SREducation/Pages/AnnualReports.aspx (20 August 2020).

Buchanan, A. (2013) The Heart of Human Rights. Oxford: Oxford University Press.

Committee on the Rights of the Child (200I) General Comment I (200I). Article 29 (I): The Aims of Education. CRC/GC200I/r. Retrieved from: https://www.ohchr.org/EN/Issues/Education/Training/Compilation/ Pages/a)GeneralCommentNorTheAimsofEducation(article29)(200I). aspx (20 August 2020).

Committee on Economic, Social and Cultural Rights (1999) General Comment 13. The right to education (Twenty-first session, 1999). U.N. Doc. E/C.12/1999/10 (1999). Retrieved from: https://www.ohchr.org/ EN/Issues/Education/Training/Compilation/Pages/d)GeneralCommen tNor3 Therighttoeducation(articler3)(1999).aspx (20 August 2020). 
Committee on the Rights of the Child. Sixty-third session (2013) Concluding observations on the combined third and fourth periodic reports of the Republic of Slovenia, adopted by the Committee at its sixty-third session (27 May - I 4 June 2013). Retrieved from: (http://docstore.ohchr.org/SelfServices $/$ FilesHandler.ashx?enc $=6 \mathrm{QkG}$ id\%2FPPRiCAq hKb7yhsiNo7UlbUkV3oM5iuiI94uROt6rFYcmjQDrxXuoIjUb6XmpG j\%2 Bry4vaS\%2BeIQg 4 LtHqUn\%2FAeN/mzSJCXr\%2BqagY\%2F 2 eVH 9viz9X\%2FsdydZItFNIA (20 August 2020).

Council of Europe (1985) Digest of Strasbourg Case - Law relating to the European Convention on Human Rights, Vol. 5. Berlin, Bonn, München: C. Heymanns Verlag.

Evropske mreže za politike izobraževanja priseljencev SIRIUS. Retrieved from: https://www.pei.si/raziskovalna-dejavnost/projekti/sirius/ (20 August 2020).

Kodelja, Z. (2012) Kritika in apologija. Ljubljana: Pedagoški inštitut.

Krek, J. (ed.) (1995) Bela knjiga o vzgoji in izobraževanju v Republiki Sloveniji. Ljubljana: Ministrstvo za šolstvo in šport.

Krek, J., and Metljak, M. (2011) Bela knjiga o vzgoji in izobraževanju v RS 2oII, Ljubljana: Zavod RS za šolstvo.

Meredith, P. (1992) Government, Schooling and the Law, London: Routledge.

Nowak, M. (1995) The right to education. In: Eide, A., Krause, C., and Rosas, A. (ed.). Economic, Social and Cultural Rights. Dodrecht: Martinus Nijhoff Publishers.

Pajer, F. (ed.) (I99I) L'insegnamento scolastico della religione nella nuova Europa. Leuman-Torino: Elledici.

Sing, K. (2014) Report of the Special Rapporteur on the right to education Privatization and the right to education (No. A/69/402). New York: United Nations. Retrieved from: https://www.ohchr.org/EN/Issues/ Education/SREducation/Pages/AnnualReports.aspx (20 August 2020).

Smernice za vključevanje otrok priseljencev v vrtce in šole (2012) Ljubljana: Zavod za šolstvo RS Slovenije. Retrieved from: http://eportal.mss. edus.si/msswww/programizor3/programi/media/pdf/smernice/cistopis_ Smernice_vkljucevanje_otrok_priseljencev.pdf (20 August 2020).

Središče Zipom (2016) Vmesno alternativno poročilo o uresničevanju konvencije o otrokovih pravicah, Ljubljana: Zveza prijateljev mladine. Retrieved from: http://www.sredisce-zipom.si/data/upload/ZIPOM_vmesno_alternativno_porocilo.pdf (20 August 2020). 
Šimenc, M. (1996) Zasebno šolstvo. In Krek, J. (ed.). Zasebno šolstvo: struktura, primerjava različnih šolskih sistemov in zakonodajne rešitve $v$ Republiki Sloveniji, pp. 9-45. Ljubljana: Ministrstvo za šolstvo in šport.

Šimenc, M. (2003) Zasebno šolstvo osem let pozneje. Šolsko polje I 4(5-6), pp. $125-136$.

Varuh človekovih pravic (2020) Letno poročilo Varuha človekovih pravic Republike Slovenije za leto 2org. Ljubljana: Varuh človekovih pravic.

Šimenc, M., and Kodelja, Z. (2015) Uresničevanje pravice do izobraževanja. In Šelih, A. (ed.). Otrokove pravice v Sloveniji: sedanje stanje in izziviza prihodnost, pp. I29-I40. Ljubljana: Slovenska akademija znanosti in umetnosti.

Šimenc, M, and Tašner, V. (2016) Komu je napoti kakovostno javno šolstvo?. Ljubljana: SVIZ.

Vlada Republike Slovenije (2010) Tretje in četrto periodično poročilo $R S$ na podlagi konvencije o otrokovih pravicah. Retrieved from: http://www.varuh-rs.si/pravni-temelji-cp/ozn-organizacija-zdruzenih-narodov/konvencija-o-otrokovih-pravicah (20 August 2020).

Zakon o osnouni šoli, Uradni list RS, št. 81/06.

Zakon o usmerjanju otrok s posebnimi potrebami, Uradni list RS, št. 58/II.

Zavod RS za šolstvo (2012) Smernice za vključevanje otrok priseljencev v vrtce in šole. Retrieved from: http://eportal.mss.edus.si/msswww/progra-

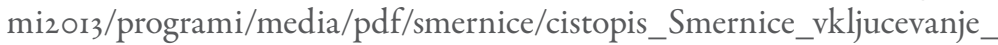
otrok_priseljencev.pdf (20 August 2020). 